\title{
Deterioro de monumentos graníticos por cristalización de sales en ambiente urbano con baja contaminación
}

\section{Decay of granite monuments due to salt crystallization in a non-polluted urban environment}

\author{
J.GARCÍA-TALEGÓN ${ }^{\star}$, M.A.VICENTE* \\ Área de Química y Geoquímica Ambiental. Instituto de Recursos Naturales y Agrobiología, CSIC \\ E.MOLINA* \\ Dpto. de Geología. Facultad de Ciencias, Univ. de Salamanca \\ (*) Unidad Asociada IRNASA/CSIC-Universidad deSalamanca
}

Fecha de recepción: 9-II-98

Fecha de aceptación: 5-VI-98

ESPAÑA

\section{RESUMEN}

Se estudia el efecto de la cristalización de sales solubles en rocas graníticas s.l. empleadas como materiales de construcción, en ambiente urbano con baja contaminación atmosférica. Las formas en que cristalizan las sales y el deterioro asociado a su presencia son analizados en granitos sanos y en otras facies que han sufrido fuertes transformaciones en cantera previas a su empleo como materiales de construcción ("alteritas").

\section{SUMMARY}

The effect of salt crystallization on granite (s.l.) rocks used as building material in an urban environment with low atmospheric pollution was studied. The manners of salt crystallization and the subsequent deterioration caused were analyzed in unweathered granite and other facies which had undergone strong transformations in quarries before being used as stone materials, "alterites".

\section{INTRODUCCIÓN}

La cristalización de sales, de naturaleza y formación variables en función de las condiciones ambientales, es el fenómeno que origina un deterioro más rápido e intenso en materiales de construcción (1-7). Estudios experimentales confirman este punto (8).

En medio urbano y con bajos índices de contaminación atmosférica, se ha comprobado que la contaminación de las aguas de escorrentía y subterráneas no profundas (7) y la influencia de morteros (9) son las fuentes de sales solubles más habituales en piedras ornamentales

\section{INTRODUCTION}

The crystallization of salts, which vary in nature and formation according to environmental conditions, is responsible for a more rapid and intense decay in building materials (1-7). Experimental studies confirm this point (8).

It has been established that in an urban environment with low indices of atmospheric pollution, the pollution of run-off and shallow ground waters (7) and the effect of mortars (9) are the most important sources of soluble salts appearing in ornamental 
$\mathrm{y}$, consecuentemente, los factores más activos en su deterioro.

En el presente trabajo se analiza la alteración producida por las sales en diferentes variedades de granito y morteros empleados en la construcción y restauración en la catedral de Ávila (ss.XII-XIV), en distintas condiciones microambientales.

\section{MATERIALES Y MÉTODOS}

La ciudad de Ávila está situada en el centro de la Península Ibérica $\left(40^{\circ} 39^{\prime} \mathrm{N}-4^{\circ} 44^{\prime} 30^{\prime \prime} \mathrm{O}\right)$, sobre una plataforma granítica a $1.100-1.200 \mathrm{~m}$ de altitud. Está sometida a un clima de tipo mediterráneo con tendencia continental y su atmósfera presenta reducidos índices de contaminación, inferiores al límite de detección de los sistemas existentes en la unidad móvil de la Consejería de Medio Ambiente de la Junta de Castilla y León. La precipitación media anual de la zona es de $370 \mathrm{~mm}$, con una humedad relativa media del aire del $57 \%$ y una temperatura ambiente anual que fluctúa entre $36,8^{\circ} \mathrm{C} \mathrm{y}-16^{\circ} \mathrm{C}$. Por término medio se registran 210 días al año con temperaturas medias mínimas inferiores a $0{ }^{\circ} \mathrm{C}$. Todo ello supone cambios hídricos y térmicos bruscos, que generan fuertes tensiones en los materiales de construcción.

Se seleccionó la catedral de Ávila por ser un monumento cuya historia constructiva está bien documentada y en el que se han empleado variedades de granito de características muy variadas y que engloban las distintas formas en que aparecen estos materiales en la naturaleza. Por otro lado, a las características climáticas generales de la zona se añaden las condiciones microambientales que aparecen en distintas partes del edificio. Los materiales de construcción dominantes son: (a) la variedad de granito "Gris Ávila" (GG), granodiorita biotítica (10) cuya composición mineralógica es cuarzo, feldespato y biotita, y (b) distintas facies graníticas, llamadas “alteritas" (GA). Estas últimas variedades son el resultado de fuertes alteraciones heredadas de tiempos geológicos pasados. En las canteras seleccionadas dichas alteraciones se manifiestan por cambios mineralógicos importantes respecto de la roca madre granítica ("Gris Ávila"), como son la aparición de arcillas (caolinita y esmectita), oxihidróxidos de hierro y ópalo CT, desaparición de las biotitas y feldespatos, según los casos, así como cambios en sus propiedades físicas (fuertes variaciones en su red poral y menor resistencia mecánica) (11). Los morteros utilizados fueron de cal, originalmente, y cemento, en las restauraciones. stones and the most active factors involved in the corresponding stone decay.

This work analyzes the deterioration effect caused by salts in different varieties of granites and mortars used in the building and restoration of historic buildings in the cathedral of Avila (12th to 14th C), which have been subjected to very diverse environmental conditions.

\section{MATERIALS AND METHODS}

The city of Avila is situated in the interior of the Iberian Peninsula $\left(40^{\circ} 39^{\prime} N-4^{\circ} 44^{\prime} 30^{\prime \prime} W\right)$, on a granite platform at an altitude of 1.100-1.200 m. It has a mediterranean climate with a continental trend and its atmosphere shows low pollution indices below the detection limit of the measuring systems of the J.C.L. Environmental Health Office mobile unit. Mean annual precipitation in the area is $370 \mathrm{~mm}$, with a mean relative atmospheric humidity of $57 \%$ and an annual temperature that fluctuates between $36.8^{\circ} \mathrm{C}$ and $-16^{\circ} \mathrm{C}$. On average, 210 days a year with minimum mean temperatures below $0{ }^{\circ} \mathrm{C}$ are recorded. All of this points to sharp hydric and thermal changes that generate strong tensions on the surface of building materials.

The cathedral of Ávila was chosen for study because it is a monument whose building history is well documented and in which varieties of granite with very diverse characteristics comprehending all the different forms in which these materials appear in nature were used. On the other hand, as well as the environmental features most characteristic of continental, non-polluted urban areas, some building specific microenvironmental conditions are present in this building. The dominant building materials are the following: (a) the "Avila Grey" variety of granite (GG), biotitic granodiorite (10), with a mineralogical composition of quartz, feldspar and biotite, and (b) different granite facies, called "alterites" (GA). These latter varieties are the result of strong weathering inherited from past geological eras. In the quarries selected, this weathering was brought about by important mineralogical changes with respect to the granite parent rock (Ávila Grey), such as the appearance of clays (kaolinite and smectite), iron oxyhydroxides and opal CT, the disappearance of biotites and feldspars, depending on the circumstances, and changes in physical properties (strong variations in their pore network and less mechanical resistance) (11). The mortars used were lime, originally, and cement in the restorations. 
Las patologías más características que se han podido observar en el edificio son placas, escamas y desagregaciones. En el muestreo de las distintas partes del edificio se ha podido detectar la existencia de sales solubles en las zonas más deterioradas, afectadas por humedades tanto de ascensión capilar como de filtraciones de tejados y terrazas.

Las sales presentes se han estudiado utilizando los métodos y técnicas que se citan a continuación:

Observación de láminas delgadas en microscopio petrográfico NIKON XTP-11 siguiendo el método empleado por el Laboratorio de Micromorfología del C.C.M.A. del CSIC, Madrid (12); previa impregnación con resina al vacío, en el pulido de láminas se emplea aceite en vez de agua, para evitar la disolución de las sales presentes.

Microscopio electrónico de barrido, empleando un equipo ZEISS DSM-940, EDAX.

Estudios térmicos ATD-TG, realizados en un equipo PERKIN-ELMER compuesto por DTA 1700 y TGS-2. En la interpretación de resultados se han tenido en cuenta los trabajos de Mackenzie (13), Paterson and Swaffield (14) y Wilson (15-16).

Difracción de rayos-X, utilizando un equipo PHILIPS PW-1730 (con goniómetro PW-1050/81, control de difractómetro PW1710 y línea de registro PW8203A). Para la identificación de los compuestos minerales se han seguido las publicaciones de Grim (17), Brindley and Brown (18) y Wilson (15-16).

Composición química total de los distintos materiales del edificio, empleando un Plasma ICP, modelo II de PERKINELMER.

La extracción de sales se realizó siguiendo la norma italiana NORMAL 13/83 (19) sobre una serie de muestras representativas de los ambientes más característicos del edificio (20). Los aniones fueron analizados por Cromatografía Líquida de Alta Presión (HPLC) con un equipo IONPAC CS10, y los cationes por absorción atómica.

La presencia de carbonatos se determinó por volumetría.

\section{RESULTADOS}

\section{1.-Rasgos Petrográficos}

a) En la variedad granito "Gris Ávila" (GG) se observan los siguientes rasgos de deterioro:
The pathologies observed most often in the buildings were plaques, scales and granular disintegration. In the sampling of different parts of the building it was detected the presence of soluble salts in the most deteriorated areas affected by damp, both from creeping and from filtrations from roofs and terraces.

The salts present were studied using the following methods and techniques:

Observation of thin layers using a NIKON XTP-11 petrographic microscope and the method used by the Micromorphology Laboratory of the C. C. M. A. of the CSIC, in Madrid (12) according to which, after impregnation with resin in a vacuum, oil is used instead of water in the polishing of the layers in order to avoid dissolving the salts present.

Scanning electron microscopy, using a ZEISS DSM-940, EDAX microscopy system.

DTA-TG thermal studies, carried out on a PERKINELMER system comprising DTA 1700 and TGS-2. The works of Mackenzie (13) Paterson and Swaffield (14) and Wilson (15-16) were taken into account in the interpretation of the results.

$X$-ray diffraction (XRD), on a PHILIPS PW-1730 equipment with a $P W-1050 / 81$ goniometer, a $P W 1710$ diffractometer control and a $P W-8203 A$ trace. For the identification of mineral compounds, the publications of Grim (17), Brindley and Brown (18) and Wilson (15-16) were followed.

The bulk chemical composition of the different materials of the building were determined on a PERKIN ELMER Plasma ICP, model II.

Salt extraction was carried out following the NORMAL Italian norm 13/83 (19) on samples representing the most characteristic environments in the building. Anions were analyzed by high pressure liquid chromatography (HPLC) with a IONPAC CS10 system, and cations by atomic absorption.

The presence of carbonates was determined by . volumetry.

\section{RESULTS}

\section{1.-Petrographic Features}

a) In the "Ávila Grey" variety of granite $(G G)$, the following signs of decay were observed: 
-Microfracturación de la roca con formación de grietas intra-, inter- y trans- minerales, la mayoría de las cuales aparecen rellenadas por sales (Fig. 1). Los feldespatos y plagioclasas están muy fracturados, pero las microfisuraciones no siguen una pauta definida (Fig. 1). En algunas de las fisuras intraminerales que presentan los feldespatos y/o sobre la superficie de los mismos se aprecia la presencia de un material (Fig. 2, F). El cuarzo aparece fragmentado y embutido en una masa salina.

-Apertura de pequeños cristales de biotita por los planos de exfoliación y precipitación de sales en los espacios creados. El deterioro de la biotita no modifica sus colores de interferencia. Hacia la superficie exterior del muro (zona de secado) aparecen placas de biotita separadas y engastadas dentro de una masa salina (Fig.2, B).

b) En la variedad "alteritas" (GA) los estudios petrográficos no permiten distinguir la presencia de cristales salinos, probablemente debido a la falta de contraste entre los rellenos arcillosos existentes en la roca original y las sales. La comparación entre los estudios petrográficos de piedras de monumento y los correspondientes a piedras de cantera permite destacar en las muestras del edificio la presencia de cavidades de gran tamaño, por pérdida del plasma de alteración (arcillas y/o ópalo CT) y aparición de fisuras, rellenas parcial o totalmente por cristales de sales, que atraviesan el plasma de alteración (Fig. 3).

El estudio petrográfico se ha completado con observaciones al MEB, donde se observa una micromorfología en forma de filamentos whisker-like (Fig. 4). Los microanálisis indican un alto contenido en nitratos y cloruros.

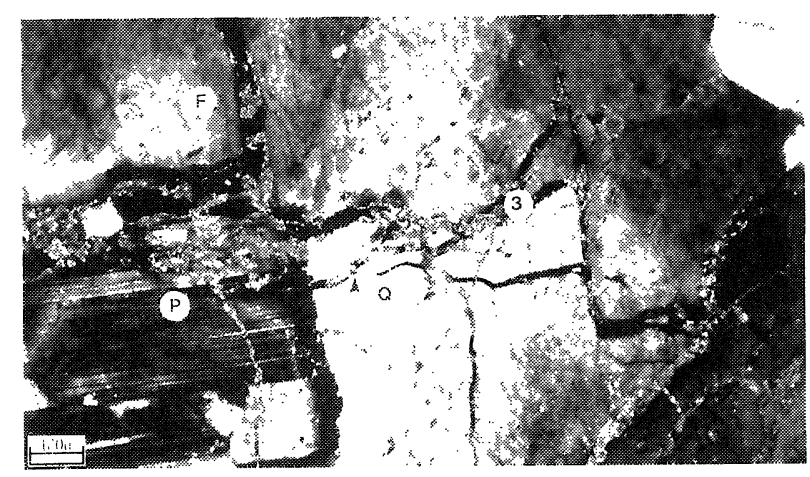

Figura 1.- Microfotografia (dos nícoles,x100) de granito "Gris Ávila" (GG). Penctración de las sales (3) a través de grietas y fisuras. $Q=$ cuarzo; $\mathrm{F}=$ feldespato; $\mathrm{P}=$ plagioclasa.

lïgure 1.- Micrograph (two nicoles, x100) of Ávila "Ávila Grey" (GG). Note penetration of salts (3) through craks and fissures. $Q=$ quartz; $F=$ fedspar; $P=$ plagioclase.
-Microfracturing of the rock with formation of intra-, inter- and trans-mineral fissures, the majority of which were filled with salts (Fig. 1). The feldspar and plagioclase were very cracked, but the microfissurings did not follow a definite pattern (Fig. 1). In some of the intramineral fissures of the feldspar and/or its surface, the presence of a material could be seen (Fig. 2, F). The quartz appeared fragmented and embedded in a saline mass.

-The aperture of small biotite crystals on exfoliation planes and the precipitation of salts in the spaces thus created. The deterioration of the biotite did not modify its interference colours. Plaques of biotite, separated and set within a saline mass, appeared toward the outer surface of the wall (drying zone) (Fig. 2, B).

\section{b) In the "alterites" variety of granite (GA),} petrographic studies did not enable us to distinguish the presence of saline crystals, probably because of the lack of contrast between the clay filling of the original rock and the salts. Comparison between petrographic studies of monumental stone and those corresponding to quarry stone highlighted the presence of large cavities in the samples from the building due to loss of the weathering plasma (clays and/or opal CT) and the appearance of fissures, partially or totally filled by salt crystals, which crossed the weathering plasma (Fig. 3).

The petrographic study of salts was completed with SEM observations which showed a whisker-like morphology (Fig. 4). Microanalysis indicated high contents of nitrates and chlorides.

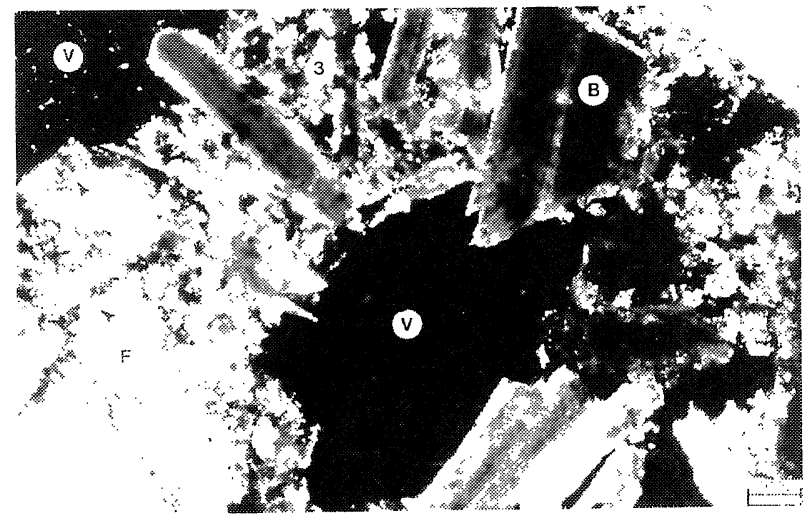

Figura 1.- Microfotografia (dos nícoles,x 100) de granito "Gris Ávila" (GG). Placas de biotita separadas por sales (3). El feldespato presenta fisuras intraminerales $(<) ; \mathrm{Q}=$ cuarzo; $\mathrm{F}=$ feldespato; $\mathrm{V}=$ espacios vacios.

Figure 1.- Micrograph (two nicoles, x100) of Avila "Ávila Grey" ( $G G)$. Note plaques of biotite separated by salts (3). The feldspar displays intramineral fissures (<); $Q=$ quartz; $F=$ fedspar; $V=$ open spaces. 


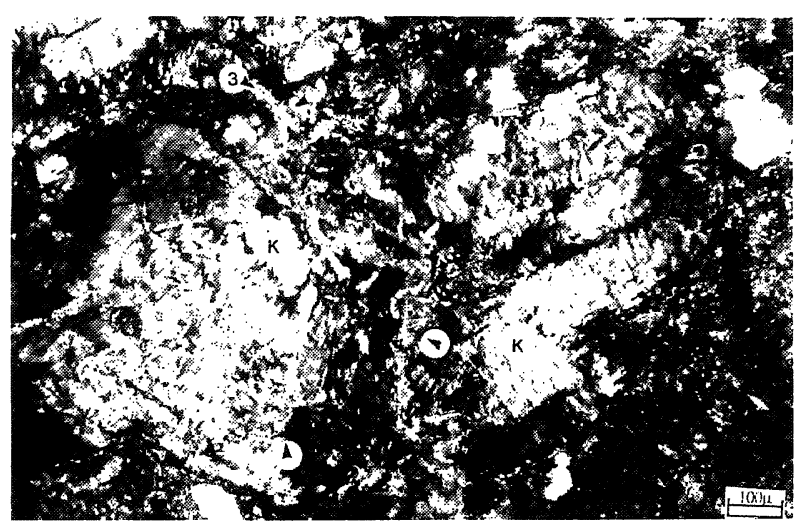

Figura 3.- Microfotográfia (dos nícoles, x100) de la variedad "alteritas" (GA) del monumento. El plasma de alteración aparece con fisuras rellenas parcial o totalmente por sales (3).

Figure 3.- Micrograph (two nicoles, x100) of the "alterites" variety (GA) of the monument. The weathering plasma appears with fissures partially or completely filled with salts (3).

\section{2.- Difracción de Rayos-X y Análisis Térmicos}

La presencia de sales en las piedras del monumento se verifica comparando los resultados de DRX y ATD-TG obtenidos sobre material de zonas degradadas (monumento) y de cantera.

Los difractogramas de rayos- $\mathrm{X}$ correspondientes a la variedad "Gris Ávila" de cantera y monumento (GG-1, GG-2, Fig. 5) presentan los efectos correspondientes a los minerales existentes en el granito (cuarzo, feldespato y mica). En las muestras de la catedral (GG-2, Fig. 5) aparecen, además, los correspondientes al yeso (7,5 $\AA$ y $3,05 \AA$ ). La reflexión a 3,05 $\AA$ puede indicar también pequeñas proporciones de calcita $o$ formas de nitratos. Algo similar ocurre en la variedad "alteritas" (GA-1, GA-2, Fig. 5). Las muestras de cantera (GA-1, Fig. 5) contienen caolinita, ópalo $\mathrm{CT}$, oxihidróxidos de hierro y cuarzo, y en las de monumento (GA-2, Fig. 5) aparecen también las reflexiones correspondientes al yeso, a 7,5 А̊ y $3,05 \AA$.

Las fases minerales presentes en el mortero de cal (Mo, Fig. 5) observadas en los difractogramas son: cuarzo, feldespato, mica y calcita. El árido utilizado sería de naturaleza cuarzo-feldespática y el ligante corresponderá a la cal, la cual, con el transcurso del tiempo, evolucionaría a calcita. Se observan igualmente reflexiones correspondientes al yeso.

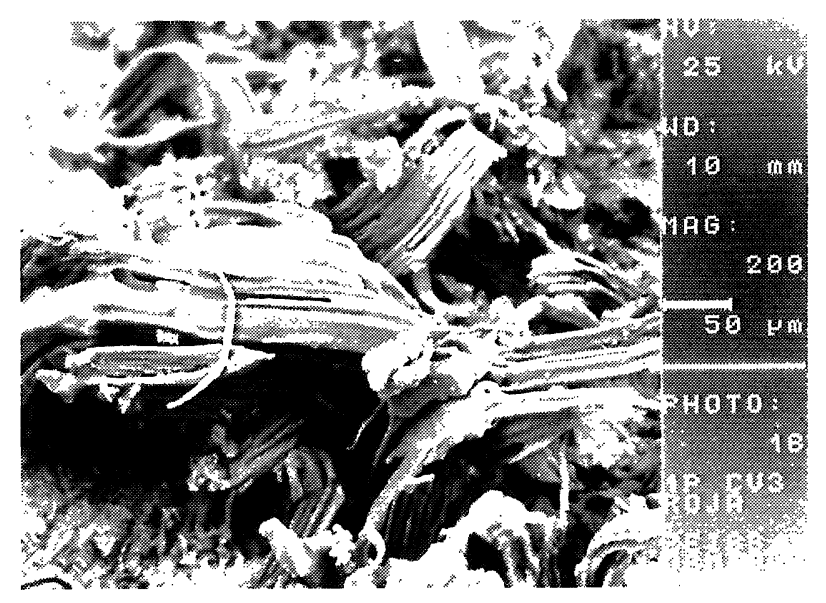

Figura 4.- Microfotografia al MEB de la variedad "alteritas" (GA). Sales cristalizadas con morfología de whiskars.

Figure 4.- SEM micrograph of the "alterites" variety (GA). Note salts crystallized with whisker-like morphology.

\section{2.-Diffraction and \\ Thermal Analysis}

The presence of salts in the building materials was confirmed by the XRD and DTA-TG results obtained with material from degraded zones (monumental stone) and from quarries.

The X-ray diffractograms corresponding to the "Avila Grey" variety of granite from quarries and from the monument (GG-1, GG-2, Fig. 5) showed the effects corresponding to the minerals existing in the granite (quartz, feldspar and mica). In the samples of monumental stone (GG-2, Fig. 5) the effects corresponding to gypsum also appeared $(7.5 \mathrm{~A}$ and $3.05 \mathrm{~A})$. The reflection at 3.05 A may also indicate small proportions of either calcite or nitrates. Similar results were found for the "alterites" variety (GA-1, GA-2, Fig. 5). The quarry rock (GA-1, Fig. 5) contained kaolinite, opal $C T$, ferrous oxyhydroxides and quartz, and in the samples from monument (GA-2, Fig. 5) the reflections corresponding to gypsum at $7.5 \mathrm{~A}$ and 3.05 A also appeared.

The mineral phases present in the lime mortar (Mo, Fig. 5) observed in the diffractograms were the following: quartz, feldspar, mica and calcite. The aggregate used would have been quartz-feldspar, and the binder would correspond to lime, which, over time, would have turned into calcite. Reflections corresponding to gypsum were also observed. 

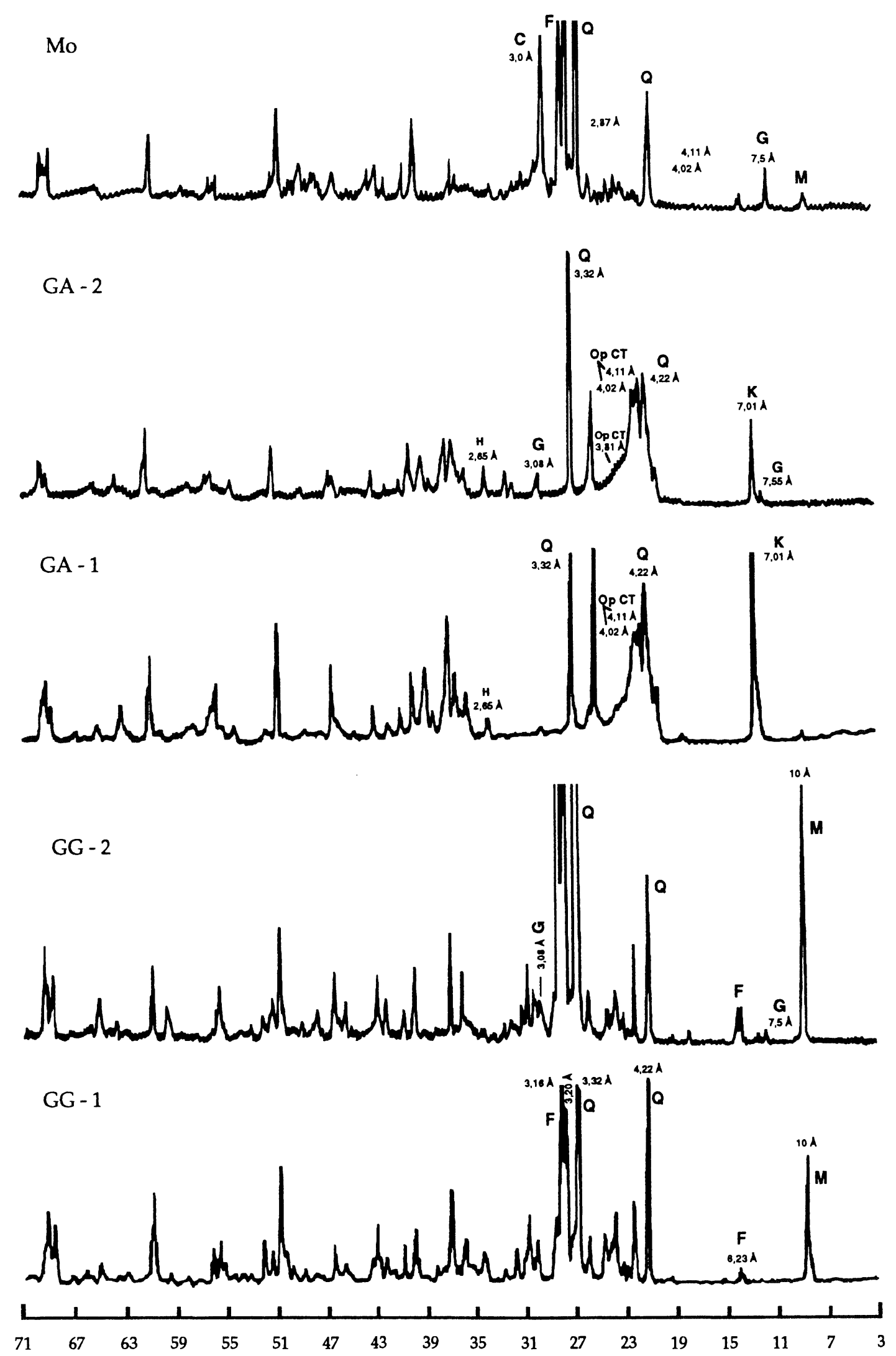

Figura 5.- Difractogramas de rayos X (roca total) de la variedad "Gris Ávila" (GG) y "alteritas" (GA) recogidas en cantera (1), monumento (2) y mortero (Mo). $\mathrm{Q}=$ cuarzo; $\mathrm{F}=$ feldespato; $\mathrm{M}=$ mica; $\mathrm{Op} \mathrm{CT}=$ ópalo $\mathrm{CT} ; \mathrm{K}=$ caolinita; $\mathrm{G}=$ yeso; $\mathrm{H}=$ oxihidróxidos de hierro; $\mathrm{C}=$ carbonato.

Figura 5.- X-ray diffractograms (bulk rock) of "Avila Grey" (GG) and "alterites" (GA) granites taken from quarry (l), monument (2) and mortar (Mo). $Q=$ quart $z ; F=$ feldspar; $M=$ mica; $O p C T=$ opal $C T ; K=$ kaolinite; $G=$ gypsum; $H=$ iron oxyhydroxides; $C=$ carbonate. 


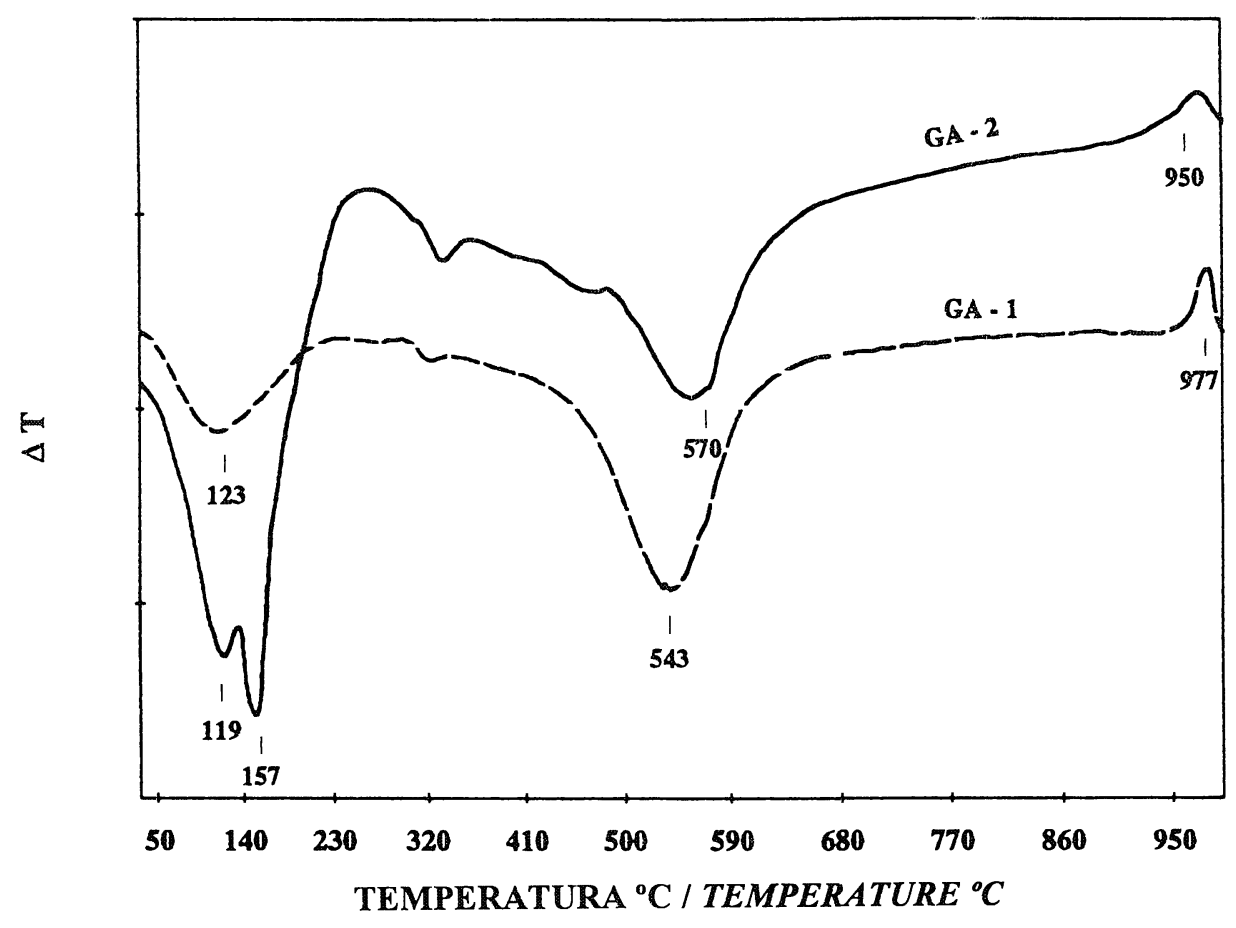

Figura 6.- Termogramas de ATD de muestras de "alteritas" en cantera (GA-1) y monumento (GA-2).

Figure 6.- DTA thermograms (bulk rock) of quarry (GA-1) and monument (GA-2) "alterites" samples.

El estudio de ATD-TG confirma la presencia de yeso en las zonas degradadas (Fig. 6). Al comparar los registros de las muestras de cantera con las de monumento se aprecia un efecto endotérmico $\left(105-123^{\circ} \mathrm{C}\right)$ en las de cantera, correspondiente a la pérdida del agua de hidratación de las arcillas, que en las muestras de las zonas degradadas (monumento) se desdobla en dos efectos endotérmicos $\left(119-157^{\circ} \mathrm{C}\right)$, correspondientes a la deshidratación del yeso (Fig. 6).

\section{3.-Análisis Químicos}

En los datos obtenidos a partir del análisis químico total se detectan los siguientes puntos de interés (Tabla 1).
The DTA-TG study confirmed the presence of gypsum in the degraded zones (Fig. 6). Comparison of the recordings of the quarry stone samples with those from the monument revealed an endothermic effect $\left(105-123{ }^{\circ} \mathrm{C}\right)$ in the quarry stone, corresponding to the loss of hydration water of the clays. In the degraded zones of the monument stone the recordings were split into two endothermic effects (119-157 ${ }^{\circ} \mathrm{C}$ ), corresponding to the dehydration of the gypsum (Fig. 6).

\section{3.- Chemical Analysis}

In the data obtained from bulk chemical analysis the following points of interest were observed (Table 1).

TABLA 1 (TABLE 1)

Composición química de las muestras

$\mathrm{GG}=$ granito "Gris Ávila"; GA = variedad "alteritas"; 1 = cantera; 2 = monumento /Chemical composition of samples

$G G$ = Ávila Grey" granite; $G A=$ "alterites" variety; 1 = quarry; 2 = monument)

\begin{tabular}{|c|c|c|c|c|c|c|c|c|c|c|c||}
\hline & $\mathrm{SiO}_{2}$ & $\mathrm{Al}_{2} \mathrm{O}_{3}$ & $\mathrm{TiO}_{2}$ & $\mathrm{Fe}_{2} \mathrm{O}_{3}$ & $\mathrm{MnO}$ & $\mathrm{MgO}$ & $\mathrm{CaO}$ & $\mathrm{Na}_{2} \mathrm{O}$ & $\mathrm{K}_{2} \mathrm{O}$ & $\mathrm{P}_{2} \mathrm{O}_{5}$ & $\mathrm{H}_{2} \mathrm{O}$ \\
\hline $\mathrm{GA}-1$ & 71,61 & 14,84 & 0,38 & 3,28 & 0,01 & 0,24 & 0,19 & 0,09 & 0,70 & 0,10 & 8,38 \\
\hline $\mathrm{GG}-1$ & 68,22 & 15,29 & 0,50 & 3,26 & 0,06 & 1,30 & 2,88 & 3,26 & 3,88 & 0,19 & 0,96 \\
\hline $\mathrm{GA}-2$ & 62,80 & 17,33 & 0,45 & 3,04 & 0,01 & 0,72 & 0,57 & 0,65 & 0,36 & 0,08 & 13,66 \\
\hline $\mathrm{GG}-2$ & 67,66 & 14,82 & 0,46 & 3,32 & 0,05 & 1,29 & 2,97 & 3,27 & 3,92 & 0,14 & 1,81 \\
\hline
\end{tabular}


Las muestras de monumento pertenecientes a las variedades ricas en ópalo, "alteritas", recogidas en zonas degradadas (GA-2) presentan un menor contenido de $\mathrm{SiO}_{2}$ que la misma variedad (GA-1) en cantera (21). Los estudios al MEB indican que este fenómeno es debido a una disolución del ópalo (Figs. 7-8), especialmente en la zona de influencia de morteros.

Los contenidos de $\mathrm{CaO}, \mathrm{MgO}$ y $\mathrm{Na}_{2} \mathrm{O}$ aumentan en la parte degradada del monumento, lo que confirma la presencia de sales en la variedad "alteritas" usada aquí (GA-2). Los aniones $\mathrm{Cl}^{-} \mathrm{NO}_{3}^{-}$y $\mathrm{SO}_{4}{ }^{2-}$ siguen la misma pauta; no aparecen en las muestras de cantera y sí están presentes en las muestras deterioradas del monumento, en mayor cantidad en la variedad "alteritas" (Tabla 2), cuya gran porosidad facilita el paso de las soluciones cargadas con tales,iones. La presencia de $\mathrm{CO}_{3}{ }^{2-} \mathrm{se}$ detectó en los morteros (Tabla 2), lo que concuerda con los datos de DRX, así como de $\mathrm{Cl}^{-}$y $\mathrm{NO}_{3}^{-}$.

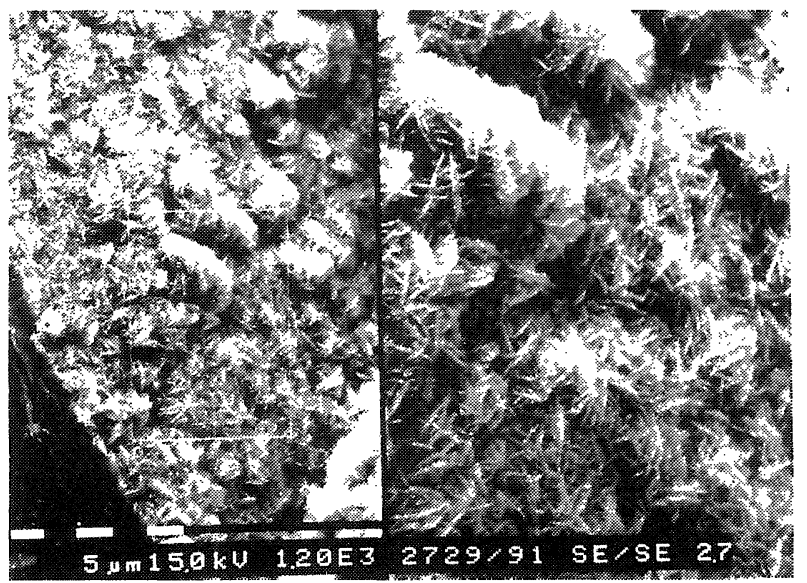

Figura 7.- Microfotografia al MEB de la variedad "alteritas" (GA) de cantera. Cavidad tapizada por pequeños cristales de ópalo CT. Algunos agregados de cristales están formando lepiesferas.

Figure 7.- SEM micrograph of the "alterites" variety (GA) from quarry. Note cavity lined with small crystals of opal CT. Some aggregates of crystals are present forming lepispheres.
The samples pertaining to opal rich varieties, "alterites", from degraded zones of the monument (GA-2) had a slight decrease in $\mathrm{SiO}_{2}$ content in a comparison to the quarry (GA-1) samples (21). SEM studies indicated that this phenomenon was due to the dissolution of opal (Figs. 7-8), specially in the area of influence of the mortars.

An increase in the contents of $\mathrm{CaO}, \mathrm{MgO}$ and $\mathrm{Na}_{2} \mathrm{O}$ in the degraded part of the monument confirms the presence of salts in the "alterites" variety used there (GA-2). The anions $\mathrm{Cl}^{-}, \mathrm{NO}_{3}^{-}$and $\mathrm{SO}_{4}{ }^{2-}$ follow the same trend. They are not present in the quarry samples whereas they are detected in the decayed samples as are in high amounts in the "alteriteS" variety (Table 2), the great porosity of which would make it easier for the solutions charged with such ions to arrive at these zones. The presence of $\mathrm{CO}_{3}{ }^{2-}$ was detected in the mortars (Table 2), this being in agreement with the $X R D$ data, as well as the presence of $\mathrm{Cl}^{-}$and $\mathrm{NO}_{3}^{-}$

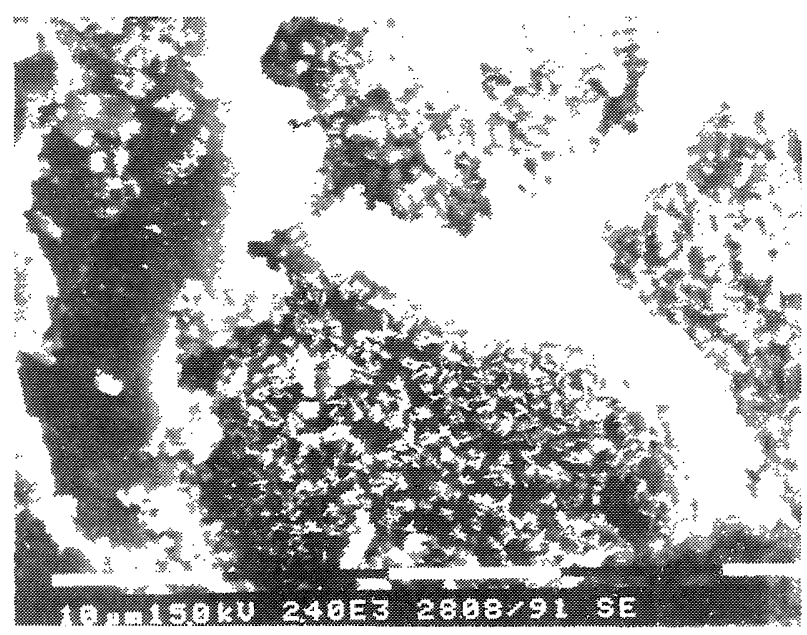

Figura 8.- Microfotografia al MEB de la variedad "alteritas" (GA) de monumento. Restos de lepiesferas rodeadas por sales.

Figure 8.- SEM micrograph of monument "alterites" variety (GA). Note remains of lepispheres surrounded by salts.

TABLA 2 (TABLE 2)

Aniones presentes en los extractos de muestras del monumento (meq/100 g). GG = granito "Gris de Ávila"; $\mathrm{GA}=$ variedad "alteritas"; Mortar = mortero; Water = agua subsuperficial y de escorrentía (P.P.M.)

(Anions (meq/100 g) present in the extracts of samples from monument. GG = "Ávila Grey" granite; GA = "alterites" variety; Mortas = mortar; Water = Underground and run-off water)(P.P.M.)

\begin{tabular}{|c|c|c|c|c||}
\hline Muestras (Samples) & $\mathrm{Cl}$ & $\mathrm{NO}_{3}{ }^{-}$ & $\mathrm{SO}_{4}{ }^{2}$ & $\mathrm{CO}_{3}{ }^{2}$ \\
\hline $\mathrm{GG}$ & $\ldots$ & 1,93 & 0,62 & $\cdots$ \\
\hline $\mathrm{GA}$ & 6,00 & 19,35 & 1,04 & $\ldots$ \\
\hline Mortero (Mortar) & 7,14 & 2,90 & 42,6 & 50,17 \\
\hline Agua (Water) & 108,25 & 209,03 & 74,74 & $\ldots$ \\
\hline
\end{tabular}


Por otro lado, se observa que las aguas subsuperficiales y de escorrentía contienen los mismos aniones que forman parte de las sales precipitadas en las paredes del edificio (Tabla 2).

\section{DISCUSIÓN}

Los resultados obtenidos demuestran que las zonas del monumento asociadas a humedades presentan abundancia de sales, detectándose en ellas diferencias de comportamiento entre el granito "Gris Ávila" (GG) y la variedad "alteritas" (GA):

Se observan fisuraciones en las biotitas de la variedad "Gris Ávila". No es posible asegurar, con los datos de que se dispone, si la fisuración de las biotitas se deberá a fenómenos de termoclastia y gelifracción con posterior relleno de las fisuras por sales, dado que las condiciones climáticas de la zona favorecen la existencia de estos fenómenos, o, si por el contrario, 'se debe exclusivamente a la cristalización de las sales. Nos inclinamos a pensar que ambos mecanismos son sinérgicos.

En las "alteritas" del edificio (GA) los procesos de deterioro provocan la formación de grandes cavidades debidas a pérdidas del plasma de alteración, con el consiguiente aumento de la porosidad total de la roca. Estos fenómenos estarían provocados por tensiones generadas durante los procesos de haloclastia y gelifracción, cambios de $\mathrm{pH}$ que afectarían a la movilidad de las arcillas que constituyen el plasma de alteración y/o posibles disoluciones del ópalo CT.

El material que aparece sobre los feldespatos y plagioclasas y que rellena las fisuras intraminerales de la variedad "Gris Ávila" (GG) pudiera originarse en un contacto de tipo reactivo entre el silicato y la disolución, cuya concentración y $\mathrm{pH}$ varían en el secado, aumentando su agresividad. Dichas reacciones son también detectables en las zonas de la variedad "alteritas" (GA) con influencia de morteros, donde, además, se aprecia una fuerte disolución de las lepiesferas de ópalo CT.

La presencia masiva de sales en las muestras situadas en zonas afectadas por humedades de ascensión capilar y por filtraciones bajo la influencia de morteros, así como la coincidencia entre aquéllas y las especies salinas en disolución en las aguas de escorrentía y subsuperficiales parecen apuntar la idea de que el origen de las mismas se encuentra en la contaminación de las aguas urbanas y en el empleo de morteros generadores de sales.
On the other hand it may be seen that the underground and run-off waters analyzed contained the same anions that formed part of the salts precipitated on the walls of the building (Table 2).

\section{DISCUSSION}

The results obtained confirm that the damp zones of the monument have an abundance of salts, differences in behaviour having been detected between the "Ávila Grey" granite (GG) and the "alterites" variety (GA).

Fissuring was observed in the biotites of the "Ávila Grey" variety. With the data available it is not possible to determine whether such fissuring was due to thermoclasty and gelifraction, afterwards being filled in with salts, since the climatic conditions of the zone favour the existence of these phenomena, or it was due to salt crystallization exclusively. We are inclined to think that both mechanisms are synergic.

Regarding "alterites" samples from monument (GA), deterioration processes have led to the formation of large cavities due to weathering plasma loss and the subsequent increase in the total porosity of the stone. These were caused by the tensions generated during the processes of haloclasty and gelifraction, by changes in $\mathrm{pH}$ that would have affected the mobility of the clays forming the weathering plasma and/or by possible dissolution of opal CT.

The material appearing on the feldspar and plagioclase and filling in the intra-mineral fissures of the "Ávila Grey" (GG) variety may have been originated in a surface reaction between the silicate and the solution, whose concentration and $\mathrm{pH}$ vary during drying, increasing their aggressiveness. These reactions can also be detected in the zones of the "alterites" (GA) variety under the effect of mortars, where a strong dissolution of the lepispheres of opal CT can also be seen.

The massive presence of salts in the samples from zones affected by capillary ascent and by filtrations under the effect of mortars, and the coincidence between those salts and the saline species appearing in solution in the run-off and ground waters seem to point to the idea that the source of them are the pollution of urban waters and the use of salt-generating mortars. 


\section{CONCLUSIONES}

Los procesos de degradación del monumento más intensos y generalizados han sido detectados en aquellas zonas del mismo afectadas por la cristalización de sales.

La aparición de sales está íntimamente relacionada con la porosidad y microfracturación del material, y su origen, en un clima con tendencia continental y baja contaminación atmosférica, se debe o está asociado a la contaminación de aguas de escorrentía y subsuperficiales (dada la acumulación de sales encontrada en los materiales de las zonas afectadas por estas condiciones) y al empleo de morteros y cementos generadores de sales solubles en la construcción y posteriores restauraciones del edificio.

En materiales originalmente poco porosos (granito "Gris Ávila") el inicio del sistema poral, que permite la cristalización interna de las sales y correspondiente degradación de la piedra, está ligado a fenómenos de termoclastia y gelifracción cuyos efectos son sinérgicos al de las tensiones de cristalización de sales.

En materiales menos compactos ("alteritas") y más porosos, la cristalización de sales se asocia con la removilización del plasma de alteración y formación de cavidades, lo que aumenta la porosidad y facilita el transporte de las soluciones a través del material; motivo principal del deterioro en el mismo.

\section{AGRADECIMIENTOS}

Los autores agradecen la ayuda de la CE (STEP CT900101), Junta de Castilla y León (project 0314/90) y CICYT(PAT91-1507-C03-01-CE).

\section{CONCLUSIONS}

The most intense and generalized decay processes in the monument were detected in zones affected by salt crystallization.

The appearance of salts is intimately related to the porosity and microfracturing of the stone. In an environment under continental climate and low atmospheric pollution the source of salts is or is associated with the pollution of run-off and ground waters (large accumulation of salts found in materials from zones affected by such conditions) and the use of salt generating mortars and cements in the building and subsequent restorations of the monument.

In materials that originally are not very porous ("Avila Grey" granite), the start of the pore system permitting internal salt crystallization and the corresponding decay of the stone is linked to thermoclasty and gelifraction, whose effects are synergic with the tensions bound to salt crystallization.

In less compact ("alterites") and more porous materials, salt crystallization is associated with the remobilization of the weathering plasma and the formation of cavities, thus increasing the porosity and facilitating the transport of solutions through the material, which is the main cause of its deterioration.

\section{ACKNOWLEDGEMENTS}

We should like to acknowledge the financial support from the EC (contract STEP CT90-0101), from the Junta de Castilla y Leon (project 0314/90) and from the CICYT (PAT91-1507-C03-01-CE).

\section{BIBLIOGRAFÍA}

(1) ARNOLD, A. AND ZEHNDER, K.: "Salts weathering on monuments", F. Zezza (ed.), 1st International Symposium on the Conservation of Monuments in the Mediterranean Basin, Bari, 1989, 31-58.

(2) CASAL PORTO, M.; SILVA HERMO, B.M. ANDDELGADO RODRIGUES, J.: "Agents and forms of weathering in granitic rocks used in monuments", N. S. Baer, C. Sabbioni and A. I. Sors (ed.), Science, Technology and European Cultural Heritage, ButterworthHeinemann Ltd., Oxford, 1991,439-442.

(3) ROBERT, M.; VERGES BELMIN, V.; JAUNET, A. M.; HERVIO, M. AND BROMBLET, Ph.: "Mise en evidence de deux microsystemes d'altération dans les monuments en granite (Bretagne)", en Proceedings of 7 th International Congress on deterioration and Conservation of Stone, LNEC, Lisbon, 1992, Vol. 1, 129-138.

(4) BERNABÉ, E. ; BROMBLET, Ph. AND ROBERT, M.: "Role de la cristallisation du natron dans la désagrégation sableuse d'un monument granitique en Bretagne", Comptes Rendus de L'Académie des Sciences de L'Institut de France, Vol. 320-2a, 1995, 571-578.

(5) GROSSI, C.M. Y ESBERT, M.: "Las sales solubles en el deterioro de rocas monumentales. Revisión bibliográfica", Materiales de Construcción, Vol. 44-235, 15-30. 
(6) ALVES, C. AND SEQUEIRA BRAGA, M.A.: "Salt systems on granitic monuments (Braga-NW Portugal)", en Degradation and Conservation of Granitic Rocks in Monuments; ed: E.C. DG XII D-1, Brussels, 1996, 109-114.

(7) VICENTE, M. A.: "Granitic materials and historical monuments: Study of weathering mechanisms and application to historical heritage conservation", en Degradation and Conservation of Granitic Rocks in Monuments; ed: E.C. DG XII D-1, Brussels, 1996, 4-44.

(8) TRUJILLANO, R.; IÑIGO, A. C.; RIVES, V. AND VICENTE, M. A.: "Behaviour of three different types of granite under forced alteration" en Degradation and Conservation of Granitic Rocks in Monuments; ed: E.C. DG XII D-1, Brussels, 1996, 89-94.

(9) O'BRIEN, P. F.; BELL, E.; PAVIA SANTAMARIA, S.; BOYLAND, P. AND COOPER, T. P.: "Role of mortars in the decay of granite". The Science of Total Environment, Vol. 167, 1995, 103-110.

(10) GARCÍA TALEGÓN, J.; MOLINA, E. AND VICENTE, M. A.: "Paleoalteraciones y silicificaciones en el relieve del Macizo Hercínico Ibérico. Empleo de los distintos niveles de alteración como materiales de construcción", III Congreso Geológico de España y VIII Congreso Latinoamericano de Geología. Excursiones, 1992, 310-319.

(11) ÍNIIGO, A. C. ; GARCÍA TALEGÓN, J.; MOLINA, E.; PÉREZ RODRÍGUEZ, J. L.; VARGAS, M. AND VICENTE M. A.: "Granitos empleados en la catedral de Ávila II", Materiales de construcción, Vol. 44, 1994, 28-37.

(12) BENAYAS, J.: "Atlas de Micromorfología de suelos e Introducción a la Micromorfología", Monografías, Vol. 84, Ed. Escuela Técnica de Ingenieros, Universidad Politécnica de Madrid, 1982.

(13) MACKENZIE, R.C.: "Differential Thermal Analysis", Vol. I, Fundamental Aspects. Ed. Academic Press, 1970, 751 pp.

(14) PATERSON, E. AND SWAFFIELD, R.: "Thermal analisis", M. J. Wilson(Ed) Blackie and Son Ltd, Determinative methods in clay mineralogy. London, 1987,308pp.

(15) WILSON, M.J.: "A Handbook of determinative methods in clay mineralogy", Blackie, London, 1987, 301 pp.

(16) WILSON, M.J.: "Clay Mineralogy: Spectroscopic and Chemical Determinative Methods", Ed. M.J. Wilson. Chapman and Hall, London, $1994,359 \mathrm{pp}$

(17) GRIM, R. E.: "Clay Mineralogy", Mc Graw-Hill Book Company, N.Y., 1962, 596 pp.

(18) BRINDLEY, G.W. AND BROWN, G.: "Crystal Structures of Clay Minerals and their X-ray Identification", Ed. Mineralogical Society, London, 1980.

(19) NORMAL 1983/13: "Dosaggio dei sali solubili", editado por M.Nimmo-ICR.

(20) GARCÍA TALEGÓN, J.; MOLINA, E.; ANDVICENTE, M. A.: "Behaviour of granitic materials under a non polluted semiarid climate (Ávila cathedral, Spain)"; ed: E.C. DG XII D-1, Brussels, 1996,61-67.

(21) GARCÍA TALEGÓN, J.; ÍÑIGO, A. C.; MOLINA, E.; PÉREZ RODRÍGUEZ, J. L.; VARGAS, M. AND VICENTE, M. A.: "Granitos empleados en la catedral de Ávila I", Materiales de construcción, Vol. 44, 1994, 23-28. 